\title{
Pfeiffer syndrome type 3
}

INSERM

\section{Source}

INSERM. (1999). Orphanet: an online rare disease and orphan drug data base. Pfeiffer syndrome type 3. ORPHA:93260

Pfeiffer syndrome type 3 (PS3) is a severe type of Pfeiffer syndrome (PS; see this term), characterized by bicoronal craniosynostosis, severe associated functional disorders, and hand, foot and elbow abnormalities. 